\title{
Indeterminação na Expressão Anímica de Eunice Katunda: uma visão interpretativa
}

\author{
Iracele Vera Livero de Souza (UNICAMP/ CIDDIC, Campinas, SP) \\ iracele.livero@gmail.com
}

\begin{abstract}
Resumo: Este trabalho tem como principal objetivo verificar os elementos de indeterminação empregados por Eunice Katunda na sua peça para piano Expressão Anímica, composta em 1979, assim como estudar os procedimentos composicionais adotados pela compositora e contribuir com os estudos sobre a música brasileira do século XX. A partir de parâmetros musicais - tempo, duração, altura e efeitos - é observado o emprego da indeterminação, assim como levantados os tipos de notação empregados - notação exata, aproximada, indicativa e gráficos musicais. A metodologia parte do estudo e análise da peça ao piano e do estudo da bibliografia específica sobre análise e notação. Serão feitas propostas para uma possível performance.
\end{abstract}

Palavras-chave: Eunice Katunda; indeterminação na música; análise musical e performance; repertório brasileiro para piano solo.

\section{Indetermination in Expressão Anímica by Eunice Katunda: an interpretative overview}

Abstract: The main objective of this paper is to verify indetermination elements used by Brazilian composer Eunice Katunda in her piano piece Expressão Anímica (1979), as well as the compositional procedures adopted by the composer. Departing from the musical parameters - time, duration, pitch and effect - the use of indetermination is analized, as well as all types of notation used in the piece - such as exact, aproximative, indicative notation and music grafics. The methodology consisted of reviewing related literature and music notation studies. Finally, a possible performance is proposed.

Keywords: Eunice Katunda; indetermination in music; musical analysis and performance; Brazilian repertory for solo piano.

\section{Introdução}

Após a segunda Grande Guerra, com o florescimento de uma vanguarda musical, o pensamento iniciado por Schoenberg no dodecafonismo e seguido por Webern e Berg, entre outros, foi além do domínio da altura do som. As composições desses mestres foram estudadas e executadas. O método que as fundamentava (serialismo ao nível das alturas) foi se expandindo para os demais parâmetros musicais como ritmo, articulação, dinâmica e timbre, resultando no serialismo integral ou serialismo total. Da mesma forma os estudos da música de Debussy e Varèse, entre outros, proporcionaram a abertura de um universo de sons - novos timbres, registros e dinâmicas. ${ }^{1}$ Olivier Messiaen ocupou um lugar de destaque, tendo importante atuação como compositor e professor, atraindo jovens que mais tarde viriam a se destacar no cenário musical, como Pierre Boulez e Karlheinz Stockhausen. Essa linha de composição se desenvolveu em vários segmentos: Milton Babitt, em suas Três Composições (1947) serializou a dinâmica associando uma particular para cada forma da série; Pierre Boulez, em sua Structures la (1952) - para dois pianos - ao desenvolver seu serialismo, utilizou para cada nota uma específica duração, dinâmica e articulação e em Kreuszpiel (1951), já utilizara essa técnica. Os compositores assimilaram plenamente o resultado do serialismo integral, utilizando-o de formas variadas e bem definidas - um modelo de música que se manteria por um período considerável de tempo. Embora o serialismo integral tenha ampliado as possibilidades composicionais, chega-se a um momento de completa estagnação - o resultado musical 
permanecia limitado, o que impossibilitava o surgimento de novas ideias. Ao mesmo tempo, as configurações rítmicas em frases cuja estrutura fora elaborada matematicamente, dificultavam e limitavam a execução para os intérpretes. Dentro de uma década, na Europa, o sistema tinha entrado em declínio ${ }^{2}$, porém, sua importância no conteúdo histórico musical não pode ser negada. Ainda que se tenha tornado a maior influência sobre os jovens compositores, o serialismo integral não foi a única linguagem deste período. Alguns compositores afastaram a questão do 'controle total' em favor de uma música livre, semelhante em alguns aspectos, porém mais variada, espontânea e com profundidade emotiva. De acordo com BRINDLE (2003, p.52-53),

[...] os compositores assimilaram o resultado do serialismo integral [...]. Os princípios rígidos deram caminho à livre invenção e a complexidade se rende a simplificação. Esta música, que pode ser chamada de livre dodecafonismo demonstrou ser durável e continuou a ser o centro da produção de vanguarda durante quinze anos.

Do ponto de vista histórico, o livre dodecafonismo é uma continuação lógica do livre atonalismo praticado nos anos que antecederam a Primeira Guerra Mundial. ${ }^{3}$ No entanto se apresenta agora em um estágio de completa maturidade musical. No livre dodecafonismo, a série é abandonada e a ordem das notas é empregada livremente. Os doze sons cromáticos são usados constantemente dentro da oitava sem nenhuma regra rígida, podendo ser repetidos quantas vezes se quiser, em conformidade com suas necessidades expressivas. ${ }^{4}$ Assim como no serialismo integral, a configuração rítmica possui as mesmas formas irregulares e proporções assimétricas, sendo, portanto, muitas vezes impossível executá-las com precisão. ${ }^{5}$ Conforme BRINDLE (2000, p.55),

[...] alguns compositores, reconhecendo estes obstáculos, criaram soluções mais simples. Este processo de simplificação conduziu à adoção de notações gráficas, que colocadas livremente, sugeriam ao intérprete o que ele poderia executar, deixando-o criar seu próprio material, embora colocassem abaixo possíveis restrições.

O desenvolvimento da composição que emprega o livre dodecafonismo foi uma espécie de fuga aos obstáculos criados pelo serialismo integral. Liberdades ao intérprete e aberturas deixadas pelo compositor sempre existiram, em menor ou maior grau na História da Música Ocidental; porém o século XX assistiu ao aparecimento de duas tendências opostas na composição: uma que parte do controle dos elementos musicais e na qual tudo é previsto e comunicado com o máximo de informações na partitura; e outra que deixa alguns parâmetros não determinados, o que permite ao intérprete diferentes escolhas.

Com esse menor controle por parte do compositor e maior responsabilidade criativa por parte do intérprete, a música adquire uma nova amplitude. Alguns elementos musicais deixam de ser determinados, e caberá ao intérprete fazer essa escolha. É o acaso fazendo parte da composição musical, deixando menos marcados os limites entre compositor e intérprete. Estes recursos foram chamados de indeterminação, música aleatória, acaso ou simplesmente improvisação (total ou controlada). Vale lembrar que estes termos foram usados livremente. Se para um determinado compositor indeterminação pode significar operações ao acaso, para outro pode ser o que é bem definido e com um pouco de liberdade apenas em alguns parâmetros musicais. Um elemento de uma peça musical é considerado indeterminado quando escolhido pelo acaso ou se a sua realização não está especificada pelas instruções através da notação musical. Em relação a este assunto KOSTKA (2006, p.285), avalia que estes dois 
processos - mudança na composição e escolha na performance - "formam as duas linhas relacionadas à música experimental, um termo que é apropriado para qualquer música na qual o produto final é mantido deliberadamente além do controle do compositor."

\section{Indeterminação: uma nova tendência do século $X X$}

O grau de indeterminação de uma obra musical pode variar muito. O acaso pode ser aplicado em alguns trechos ou na peça inteira; pode ser parcial, quando aplicada em apenas alguns elementos (como altura ou duração), ou total quando aplicado a todos os elementos da composição. Embora a indeterminação na música tenha sido um fenômeno difundido na Europa por volta dos anos 50, observa-se que nos Estados Unidos um grupo de compositores já havia utilizado elementos indeterminados em suas obras, nas primeiras décadas do século XX. Charles Ives, na peça Sonata n. 1, (1902-1910) coloca indicações de repetir 'duas ou três vezes' um mesmo compasso ou a possibilidade de manter um acorde por cinco compassos. Henry Cowell, na peça Mosaico (1934-1935), deixa os intérpretes decidirem sobre a ordem em que os fragmentos da partitura serão organizados. Uma das peças de Cowell mais ousada da época foi The Banshee (1925), na qual o executante produz alturas fixas e deslizantes através da manipulação do encordoamento no interior do piano. A escrita para piano foi um campo particularmente fértil para aqueles interessados em experimentar novos sons. No entanto, a maior referência no uso do acaso partiu do compositor americano John Cage nos anos 40, com o seu Piano Preparado. Cage utiliza recursos de outros materiais ${ }^{6}$, dispostos entre as cordas do piano para produzir novas sonoridades. ${ }^{7}$ De fato, para compositores como Stockhausen, Boulez e Berio, ancorados na extrema precisão do serialismo integral, essa abertura foi particularmente difícil. Sobre esse assunto, BRINDLE (2003, p.68) relata que "[...] a tradição musical europeia foi construída sobre o princípio de que a música só pode incluir sons precisos, tocados em momentos exatamente definidos e aqueles sons indefinidos, tocados ao acaso, só poderiam produzir uma no music." Boulez, apesar da admiração por Cage (que era recíproca, até que a divergência estética os separasse), seguiu destino diferente. Na Correspondência Boulez-Cage (1949-1954), os dois importantes compositores esclarecem os caminhos seguidos por eles: Boulez defende 0 serialismo integral e o uso do acaso controlado, enquanto Cage parte para a indeterminação total. Estas duas vertentes - serialismo e indeterminação - apesar de figurarem como correntes opostas contribuíram para a construção de um novo discurso musical e romperam com a linearidade do pensamento. Conforme esclarece CAMPOS (1998, p.153), "pode-se reconhecer convergências e mútuas influências entre elas." Quanto à indeterminação como técnica do século XX, SIMMS (1986, p.369) explica que "a aplicação da indeterminação foi chamada 'aleatória' por escritores europeus, como Boulez e Lutoslawski, para distingui-la das aplicações mais extensas do acaso entre os compositores americanos." Ainda que ocorram divergências na concepção e na consideração dos termos, o uso do acaso, como técnica de composição é conhecido por teóricos pelo nome genérico de indeterminação. ${ }^{8}$

\section{A indeterminação na música brasileira}

O cenário da criação musical no Brasil, durante as décadas de 1940 e 1950 consiste da influência de duas tendências: por um lado compositores nacionalistas que pesquisavam e assimilavam material musical de origem folclórica e popular, empregando-o conforme estruturas formais consagradas; e por outro, compositores que procuravam novos caminhos de expressão e de liberação de todas as normas. A contribuição à modernização da composição musical brasileira inicia-se com um grupo de novos compositores que, com ou sem uma primeira formação acadêmica, se entregaram às 
descobertas de novas perspectivas de organização do espaço musical. KATER (2000, p.15) menciona que o Grupo Música Viva9, "torna-se responsável por um intenso movimento de revitalização artística, pedagógica e cultural." Este movimento de vanguarda musical terá como proposta o advento de uma nova era, sem que haja lugar para preconceitos e receitas acadêmicas. O Grupo de Koellreutter tinha como objetivo acompanhar e situar a música brasileira em conformidade com as novas experiências musicais européias. O serialismo integral teve influência sobre estes compositores que haviam se dedicado ao dodecafonismo. ${ }^{10}$ Consequentemente, os caminhos do pósserialismo foram os mais seguidos pelos compositores brasileiros, provavelmente porque compreendiam a síntese buscada: princípios estruturais definidos, porém não excessivamente rígidos (abertura à indeterminação) e, portanto em acordo com o ideal de expressão buscado por eles. NEVES (1977, p.154) relata que "a influência de Cage sobre esses compositores brasileiros foi das mais importantes, levando-os a questionamentos que colocavam em jogo não só as diferentes maneiras de criar, mas o próprio ato criador." Ocorrem desse modo as primeiras experiências aleatórias por compositores brasileiros.

Criada por um grupo de poetas que lançavam as bases da poesia concreta surge em São Paulo a revista Invenção que, no seu terceiro número apresenta o manifesto Música Nova: compromisso total com o mundo contemporâneo. Reflete a preocupação de músicos e compositores, entre os quais Damiano Cozzella, Rogério Duprat, Gilberto Mendes e Willy Correia de Oliveira. ${ }^{11} \mathrm{O}$ compositor Gilberto Mendes (citado por SANTOS, 1995, p.187) esclarece:

\begin{abstract}
Nós, como Grupo Música Nova, somos pioneiros de toda a espécie de vanguarda imaginada no Brasil. Música aleatória, teatro musical, microtonalismo em música, toda a estética do estrutural, do serialismo integral, nós somos os pioneiros de todas estas manifestações. Isto é o que nos difere do Manifesto Música Viva que era eminentemente schoenberguiano, enquanto o Música Nova vigorou no sentido Boulez/Stockausen para frente, ou seja, outra linha.
\end{abstract}

Como uma técnica de composição surgida a partir da segunda metade do século XX, pode-se observar que ainda há a necessidade de melhores estudos e informações sistematizadas na música brasileira. Assim, este estudo foca a compositora Eunice Katunda, membro do Grupo Música Viva e sua contribuição para a indeterminação na música brasileira. Eunice Katunda (1915-1990) assumiu uma postura político-ideológica de forma visceral e, dessa mesma maneira, buscou uma criação legítima apoiada em manifestações do folclore nacional. Anos mais tarde, realiza um percurso semelhante ao do seu companheiro Santoro e retoma a música mais amplamente, como um laboratório expressivo. Compõe em 1979 Expressão Anímica, uma peça que utiliza elementos indeterminados em sua composição. Dedica essa obra a H.J. Koellreutter, o mentor do Música Viva e seu ex-mestre. A peça Expressão Anímica foi estreada em Santos, no XV Festival Música Nova (27 de setembro de 1979) e foi dedicada aos signatários do Manifesto Música Viva de 1946. O Jornal O Estado de São Paulo, numa cobertura jornalística não assinada, faz referência a esse dia:

[...] O sexto dia do XV Festival Música Nova de Santos - na última quinta-feira - foi inteiramente dedicado aos signatários do Manifesto Música Viva, que surgiu em 1946, marcando uma nova tendência na arte musical, no Brasil. A pianista e compositora Eunice Katunda, participante do movimento, interpretou antigas e recentes obras de seus companheiros, além de Expressão Anímica composta por ela este ano." (O Estado de São Paulo,1979, p.18) ${ }^{12}$ 
Esse estudo pretende analisar e esclarecer os procedimentos composicionais empregados pela compositora na peça Expressão Anímica, observando o emprego da indeterminação bem como levantando os demais tipos de material utilizados na peça. Parte das seguintes questões: quais os elementos de indeterminação empregados pela compositora na Expressão Anímica? Qual a participação do intérprete na criação da obra? Ao procurar solucionar estas questões, o presente estudo tem por finalidade dar enfoque à aplicação dessa técnica na obra pianística de Eunice Katunda, através da peça Expressão Anímica, tornando possível verificar o grau de inserção e de participação do intérprete. Paralelamente, pretende-se fazer o registro da grafia musical empregada pela compositora bem como suas respectivas interpretações.

\section{Análise: Expressão Anímica}

$\mathrm{Na}$ Expressão Anímica, Eunice Katunda emprega tipos de notação da linguagem tradicional, assim como símbolos que denotam os novos procedimentos composicionais e revelam a preocupação da autora na ampliação dos conceitos básicos da linguagem musical. O presente estudo pretende fazer uma abordagem da escrita musical empregada na peça como uma representação dos sons, observando a forma de registro dessa informação musical e, ao lado do estudo das técnicas da composição, trazer subsídios para uma possível interpretação. Com base nesta proposta as investigações se apoiaram em Erhard Karkoschka (1972, p.19), que classifica a notação segundo quatro tipos principais: (a) notação exata, (b) notação aproximada, (c) notação indicativa e (d) gráficos musicais. O autor não explica o que significa cada termo, apenas afirma que "[...] a notação está dividida em quatro níveis; enquanto a precisão da notação diminui entre um nível e outro, a importância do efeito gráfico aumenta".

Para esta análise propõem-se os seguintes termos com as respectivas definições: ${ }^{13}$

(a)notação exata - tipo de notação que visa um maior grau de precisão;

(b)notação aproximada - significa que existem possibilidades de escolha dentro de limites fixos;

(c)notação indicativa - não limita rigorosamente, mas deixa livre do rígido padrão de compasso e permite ao intérprete sentir, mais do que contar, as proporções qualitativas das durações;

(d)gráficos musicais- escrita imaginativa em forma de desenhos/arabescos ou outros tipos de ilustrações sugestivas.

KARKOSCHKA (1972, p.19) explica que, muitas vezes, os limites entre estes quatro tipos de notação não são muito claros e que o mesmo símbolo pode ser classificado de diferentes maneiras, dependendo do contexto no qual se encontra e da finalidade para a qual se destina. Do ponto de vista do intérprete, a notação pode ser considerada como um dos aspectos mais relevantes da peça. É através da grafia empregada que a compositora irá determinar o grau de liberdade dado ao intérprete no momento da execução. Por intermédio da decodificação correta destes símbolos (muitas vezes sem a devida clareza) e das instruções o intérprete poderá realizar uma interpretação coerente.

\subsection{Justaposição de Módulos}

A peça apresenta vinte Módulos constituídos de materiais diversos que empregam uma tipologia quanto à altura, ritmo, duração, timbre e intensidade. Alguns Módulos são determinados, outros, porém, apresentam uma estrutura livre para o intérprete. A partir do 
material de Expressão Anímica tem-se como característica relevante a exploração do timbre. Para melhor compreensão quanto aos elementos determinados e indeterminados, esta análise foi subdividida em duas categorias: trechos musicais executados no teclado do piano e trechos musicais executados no encordoamento do piano.

Levando-se em consideração que $(A)$ indica os trechos executados no teclado e $(B)$ os realizados no encordoamento do piano, cada Módulo se apresenta conforme demonstra 0 Ex.1:

\begin{tabular}{|c|c|c|c|c|}
\hline Mod. 1 & Mod. 2 & Mod. 3 & Mod. 4 & Mod. 5 \\
A & B/A & A & B & B/A \\
\hline Mod. 6 & Mod. 7 & Mod. 8 & Mod. 9 & Mod. 10 \\
A & A & A & B & A \\
\hline Mod. 11 & od. 12 & Mod. 13 & Mod. 14 & Mod. 15 \\
B/A & A & B/A & A & A \\
\hline Mod. 16 & Mod. 17 & Mod. 18 & Mod. 19 & Mod. 20 \\
A/B & A & A & B & B \\
\hline
\end{tabular}

Ex.1-Módulos $\mathrm{A}$ (executados no teclado) e $\mathrm{B}$ (executados nos encordoamentos do piano) em Expressão Anímica de Eunice Katunda.

\subsection{Símbolos e indicações}

Os exemplos a seguir relacionam os símbolos e as indicações que ocorrem em Expressão Anímica e suas respectivas maneiras de executar ao piano, conforme os seguintes parâmetros:

(a) Tempo - com base no andamento em que se interpretará cada Módulo.

(b) Duração - conforme ANTUNES (1989, p.75) "[...] no processo do fenômeno musical verifica-se a existência de dois tipos de duração: a duração física e a duração psicológica. A primeira pode ser medida com um cronômetro; a segunda não. A primeira é absoluta, enquanto a segunda é relativa e subjetiva."

(c) Altura - conforme ANTUNES (1989, p.23) é o "que permite situar o som em um espaço escalonado imaginário, de modo a relacionarmos quanto um é mais agudo ou mais grave que outro."

(d)Tempo, duração e altura - enfatizam os três parâmetros simultaneamente.

(e) Efeitos - característica tímbrica em diferentes níveis de intensidade.

\subsubsection{Tempo}

As expressões $10 \times 56$ ca.; $10 \times 46$ ca.; 3 × 40 e $5 \times 56$, indicam que deve-se sustentar a nota cerca de 10, 3 ou 5 batidas do metrônomo sugerido. Outras expressões de tempo como rápido, muito lento, menos lento também são encontradas na peça.

\subsubsection{Duração}

Os Exs. $2 a, 2 b$ e $2 c$ mostram os símbolos empregados quanto à duração. $O$ pedal do instrumento explora a ressonância dos sons e é um recurso necessário para esta execução. 


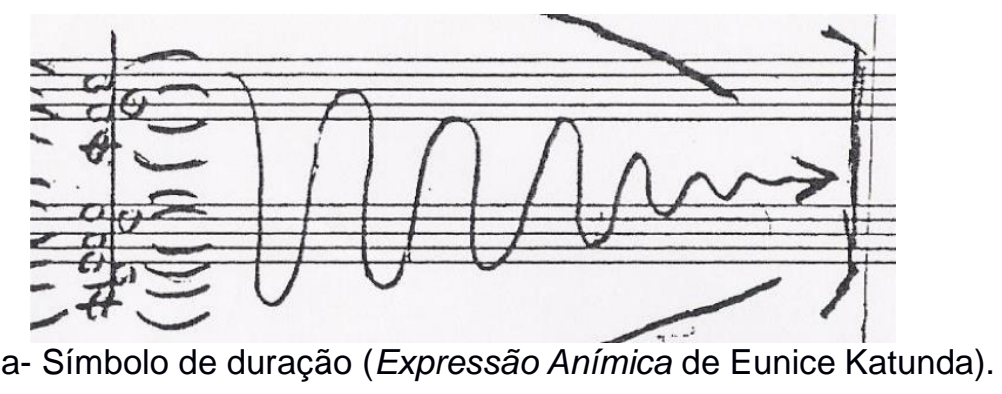

Ex.2a- Símbolo de duração (Expressão Anímica de Eunice Katunda).
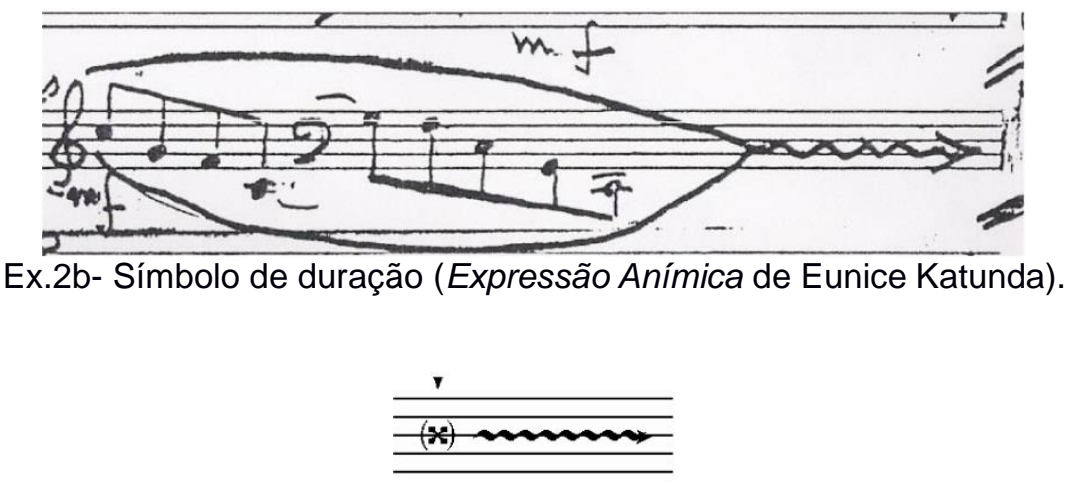

Ex.2c- Símbolo de duração (Expressão Anímica de Eunice Katunda).

\subsubsection{Altura}

Alguns dos símbolos empregados para a altura necessitam do uso de uma dedeira. Notese que a compositora emprega diferentes símbolos para uma mesma execução. Os Exs. 3a, 3b e 3c mostram estes símbolos:

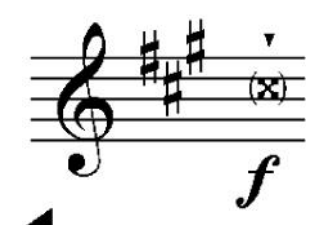

Ex.3a-Símbolo de altura: uso de dedeira no encordoamento do piano.

(Expressão Anímica de Eunice Katunda).

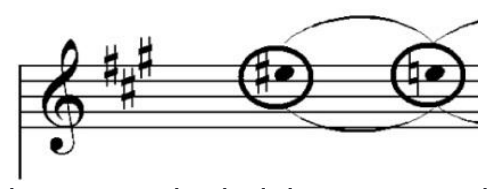

Ex.3b-Símbolo de altura: uso de dedeira no encordoamento do piano.

(Expressão Anímica de Eunice Katunda).

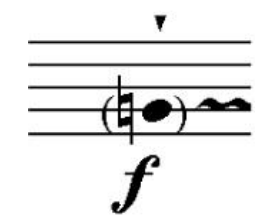

Ex.3c-Símbolo de altura: uso de dedeira no encordoamento do piano.

(Expressão Anímica de Eunice Katunda). 
Ainda ocorrem símbolos que determinam apenas a região do instrumento os quais deverão ser tocados e as expressões registro médio e registro grave, como mostram os Exs. 4a e 4b:

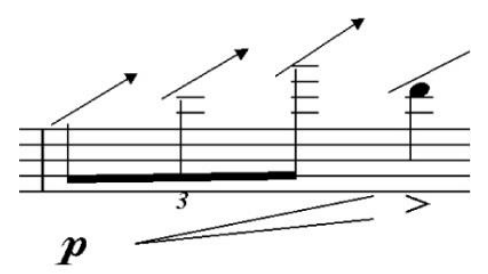

Ex.4a-Símbolo para região: glissando com dedeira no encordoamento do piano.

(Expressão Anímica de Eunice Katunda).

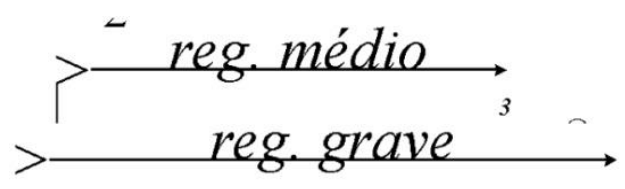

Ex.4b-Símbolos para registro do piano. (Expressão Anímica de Eunice Katunda).

Para ser executado com uma baqueta ou com um prato no encordoamento do piano, empregam-se os símbolos demonstrados no Exs. 5a e 5b. Note-se que a execução com o prato determina apenas a região do instrumento enquanto que com as baquetas, a altura está determinada.

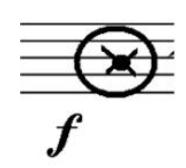

Ex.5a-Símbolos: executado com um prato e com uma baqueta de feltro.

(Expressão Anímica de Eunice Katunda).

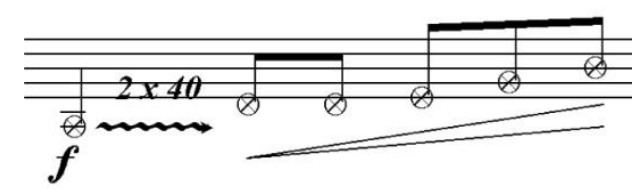

Ex.5b-Símbolos: executado com um prato e com uma baqueta de feltro. (Expressão Anímica de Eunice Katunda).

Ocorre ainda cluster com alturas delimitadas entre as teclas pretas e brancas do piano. Determinado pela compositora, os clusters deverão ser tocados com a palma das mãos e com os antebraços. Observe-se os Exs. 6a e 6b:

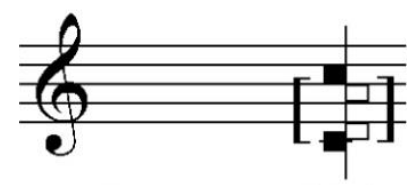

Ex.6a-Clusters: alturas determinadas, executados com a palma da mão.

(Expressão Anímica de Eunice Katunda). 


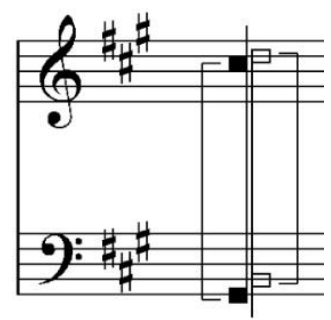

Ex.6b-Clusters: alturas determinadas, executados com o antebraço.

(Expressão Anímica de Eunice Katunda).

\subsubsection{Efeitos}

O símbolo demonstrado no Ex.7 apresenta uma total liberdade na interpretação. No âmbito das regiões estipuladas, com notas ascendentes e descendentes, o intérprete deverá criar efeitos de ondas (in waves).

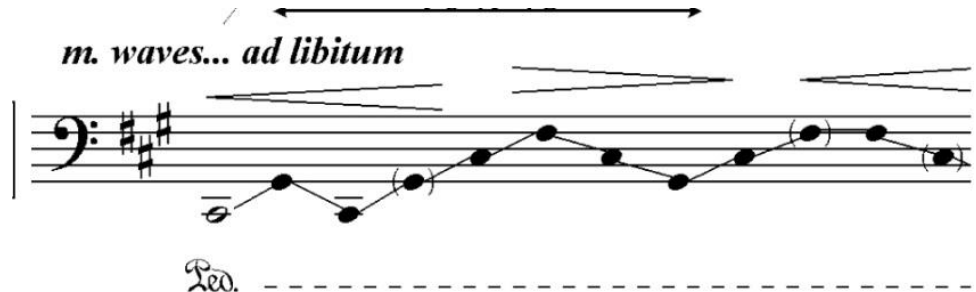

Ex.7-Efeitos de ondas: liberdade de interpretação. (Expressão Anímica de Eunice Katunda). Ao se permitir a repetição ad libitum no trecho proposto, este símbolo dá certa liberdade ao intérprete, como mostra o Ex.8:

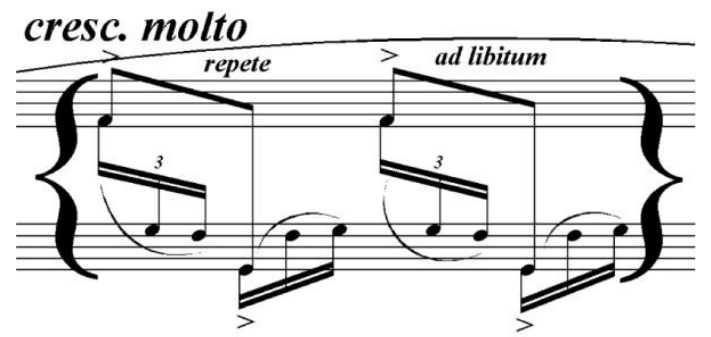

Ex.8-ad libitum, certa liberdade ao intérprete. (Expressão Anímica de Eunice Katunda).

\subsection{Elementos musicais determinados e indeterminados}

Por elementos de escrita determinada compreendem-se aqueles cuja notação musical segue parâmetros fixos de altura, ritmo, dinâmica e timbre; e por elementos indeterminados, entendem-se aqueles que apresentam partes em aberto e que o intérprete deve decidir, o que lhe permite uma variedade de escolhas.

Módulo 1(A). Apresenta a Ideia 1 escrita sobre as teclas pretas do piano e de direção descendente, explorando a ressonância do conjunto dos sons através da sustentação do pedal direito do instrumento (mesmo que não indicado pela compositora). A peça determina que a duração é $10 \times 56$ ca.. Esta citação faz referência ao período de sustentação, a partir da execução de todos os sons, para efeito de ressonâncias, pois não está indicado em qual andamento deve-se executar cada nota. A duração do som está expressa através de uma linha sinuosa, contínua de comprimento e que sugere o declínio das ondas sonoras. Mesmo com a indicação, é empregado o tipo de notação aproximada. Ao observar os andamentos propostos em trechos similares a este, sugere-se ao intérprete um andamento de MM.144 para cada colcheia. O tempo, por conseguinte, está 
indeterminado e cabe ao intérprete tomar essa decisão. Para a altura, dinâmica e articulação, foi empregado o tipo de notação exata. A intensidade é definida em $\mathrm{ff}$ assim como a articulação se propõe um non legato. Cada uma das pequenas ligaduras sobre cada som deve vir acompanhada de sua ressonância (prolongamento amortecido naturalmente). O intérprete deve dar ênfase a esse Módulo, visto que apresenta a Ideia principal que irá ser apresentada inúmeras vezes no decorrer da peça. Observe-se o Ex.9:

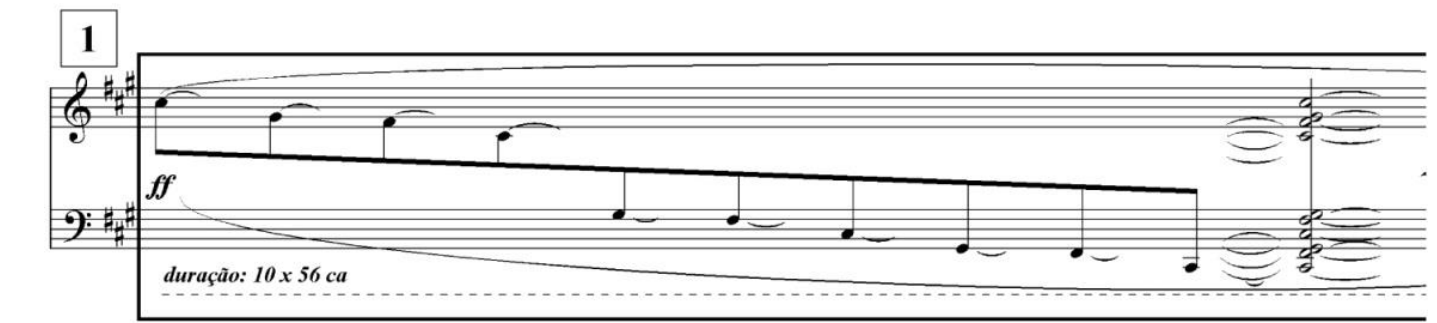

Ex.9 - Módulo 1 de Ideia 1: tempo e duração indeterminadas, dinâmica determinada (Expressão Anímica de Eunice Katunda).

Módulo 2(B/A). É executado no encordoamento do piano com o uso de uma dedeira e, no final do Módulo, no teclado com a reapresentação da Ideia $1 \mathrm{em} \mathrm{mf}$. Apresenta notação exata quanto à altura, intensidade e articulação nas duas maneiras de explorar o instrumento (teclado e encordoamento). As notas dedilhadas no encordoamento antecipam a linha melódica que será apresentada no Módulo 3, porém com a duração indeterminada. O tipo empregado para a duração é notação indicativa, expressa através de uma linha contínua de comprimento proporcional. A compositora não especifica o tempo deste Módulo e cabe ao intérprete tomar decisões, realizando o ritmo e as durações através da avaliação dos comprimentos dos sons por meio de uma correlação espaço-tempo. Outra sugestão para o intérprete é a realização da segunda parte deste Módulo como se fosse um eco. Observe-se o Ex.10:

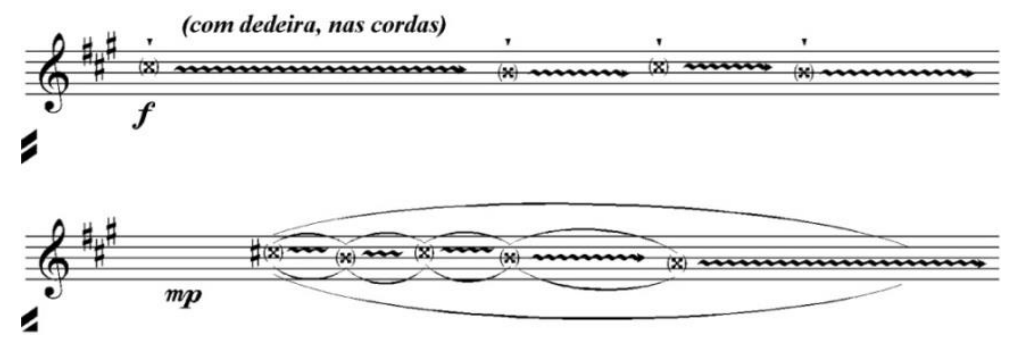

Ex.10-Módulo 2: tempo e duração indeterminadas, dinâmica determinada e duração proporcional ao comprimento das linhas (Expressão Anímica de Eunice Katunda).

Módulo 3(A). Inteiramente executado no teclado. Todos os elementos são determinados. Uma única indicação de duração indeterminada ocorre no final do Módulo, com o emprego da fermata sobre a nota Dó. O tempo apresenta uma notação exata, assim também como para altura, duração, ritmo e articulação. Inicia-se com uma linha melódica na região aguda do instrumento com a seguinte citação - Kausika. ${ }^{14}$ Esta linha se repete com inclusão de novos sons, seguida de uma reapresentação da ldeia 1 (Módulo 1) com variação em menor extensão e arpejos. A dinâmica não está indicada, mas propõe-se que o intérprete realize os dois trechos com intensidades diferenciadas: a primeira vez forte e a segunda mezzo piano, lembrando-se de concluir o trecho sobre um sfz. Observe-se o Ex.11: 


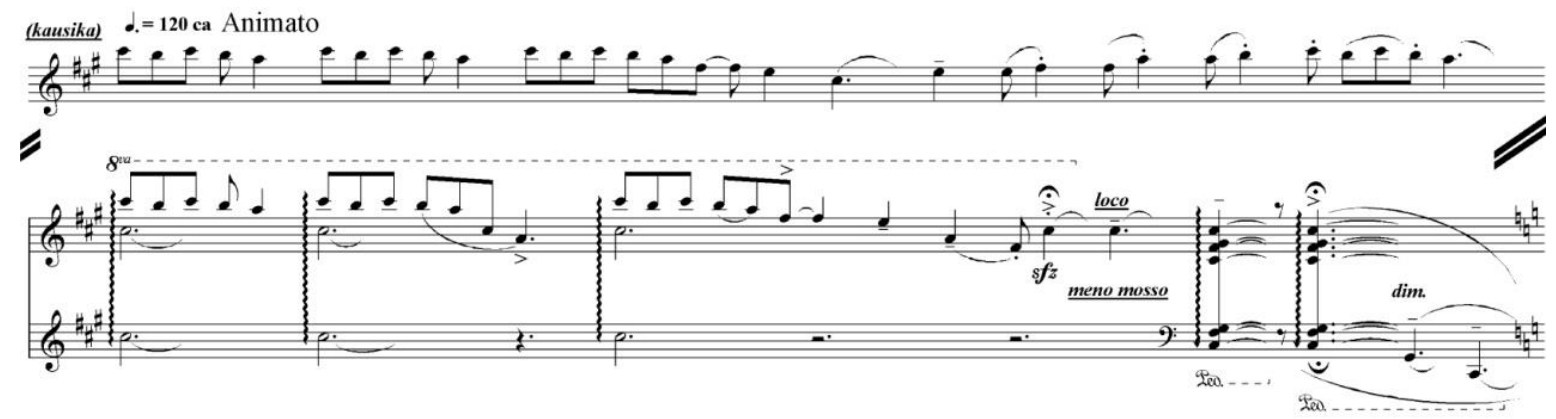

Ex.11-Módulo 3 com variação da Idéia 1: altura, tempo e duração determinadas. (Expressão Anímica de Eunice Katunda).

Módulo 4(B). Inteiramente tocada no encordoamento do piano com uso de uma baqueta de feltro. A altura é relativa, com indicação apenas de registro grave e registro médio. $\mathrm{O}$ intérprete, ao bater com a baqueta na região sugerida, produzirá um efeito percussivo abrangendo um número de harmônicos. Para a altura, emprega a notação aproximada, pois dentro dos limites propostos existem possibilidades de escolha. O ritmo está determinado na maioria dos grupos de sons, apesar de não haver marcação de compasso. Deve-se tocar com base na proporção dos valores, exceto para duas notas longas, onde se observa uma linha contínua e a expressão deixar vibrando. O tempo está determinado apenas sobre alguns sons $(2 \times 40)$ e da palavra apressando no final do Módulo. Quanto à dinâmica e a articulação, o tipo de notação é exata. O intérprete deve decidir com antecedência quais alturas apresentam um melhor resultado dentro do contexto musical, principalmente aquelas tocadas no registro médio. O pedal não está indicado e deve ser colocado apenas para as batidas prolongadas. Observe-se no Ex.12 o tipo de notação utilizada pela compositora:

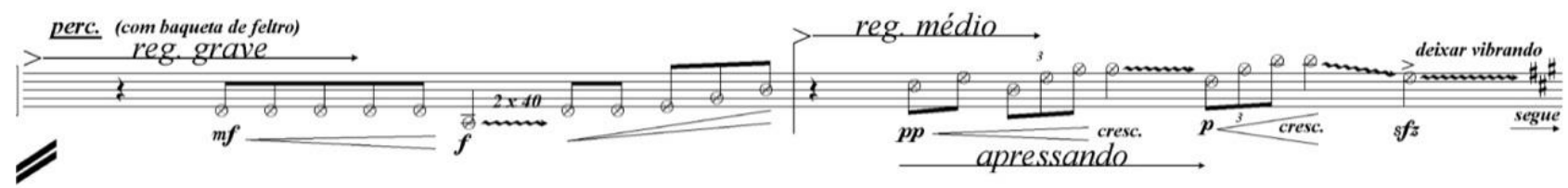

Ex.12-Módulo 4: altura indeterminada, ritmo e dinâmica determinados. (Expressão Anímica de Eunice Katunda).

Módulo 5(A/B). Explora recursos dos dois timbres: no teclado e no encordoamento do piano com o uso da dedeira. A altura tem a notação exata nos dois recursos tímbricos, assim como a dinâmica. O tempo está determinado, porém a compositora indica uma linha de sustentação dos sons, o que torna a duração um elemento indeterminado, cabendo ao intérprete essa decisão. A duração se torna indefinida também no emprego das apojaturas: as duas primeiras devem ser tocadas de maneira mais curta possível no encordoamento e as duas últimas apojaturas mais longas, cabendo ao intérprete decidir. Outro fator importante de observação é que não se deve interromper o som nas passagens do Módulo 4, 5 e 6. A expressão segue confirma esta continuidade, como se pode observar no Ex.13: 


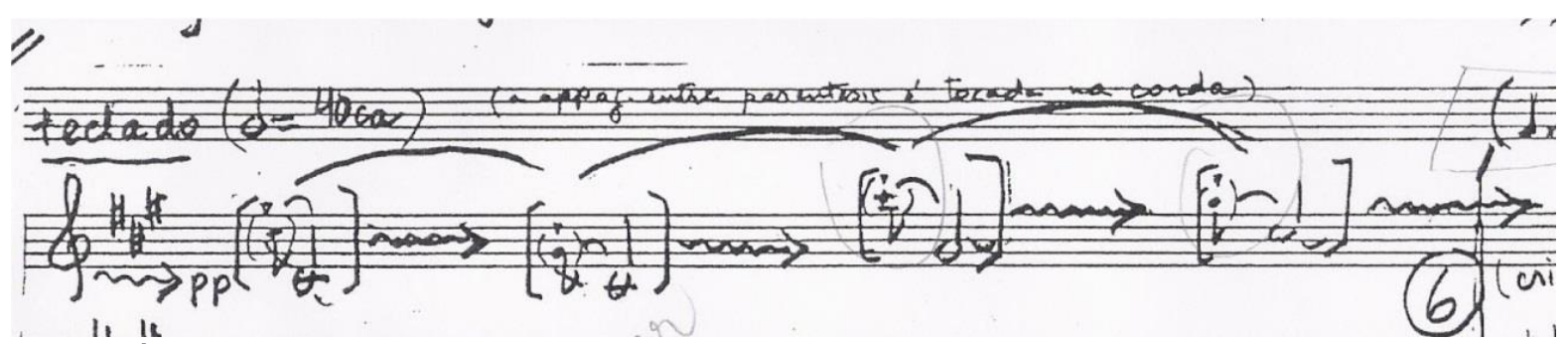

Ex.13-Módulo 5 no encordoamento com uso de dedeira: altura determinada e duração indeterminada.

(Expressão Anímica de Eunice Katunda).

Módulo 6(A). Este Módulo tocado inteiramente no teclado apresenta um motivo - Tema do Sonho - na região aguda do instrumento. Este motivo vem intercalado com a Ideia 1, com arpejos e dinâmica diferenciada. O tempo está determinado com tipo de notação exata, enquanto que a duração se alterna entre determinada e indeterminada. Existe um paradoxo na notação: a compositora indica o tempo ( $3 \times 40)$, porém emprega uma linha de sustentação dos sons, deixando o intérprete livre para decidir. A dinâmica e as articulações apresentam um tipo de notação exata. Verifica-se também a preocupação com o recurso tímbrico, no emprego da expressão cristalino e nos contrastes das Ideias em regiões opostas do piano. A Ideia 1 parece calar a Ideia 2, pois surge antes que a mesma se conclua. Observe-se os Exs.14a e 14b:

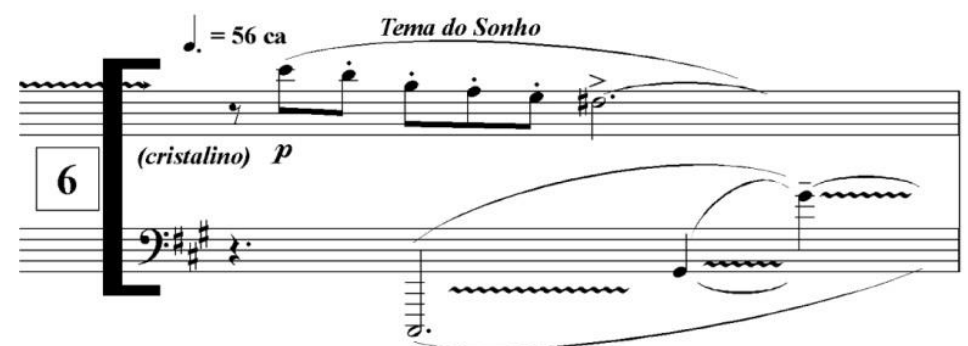

Ex.14a-Módulo 6 com Tema do Sonho: altura determinada e duração indeterminada. (Expressão Anímica de Eunice Katunda).

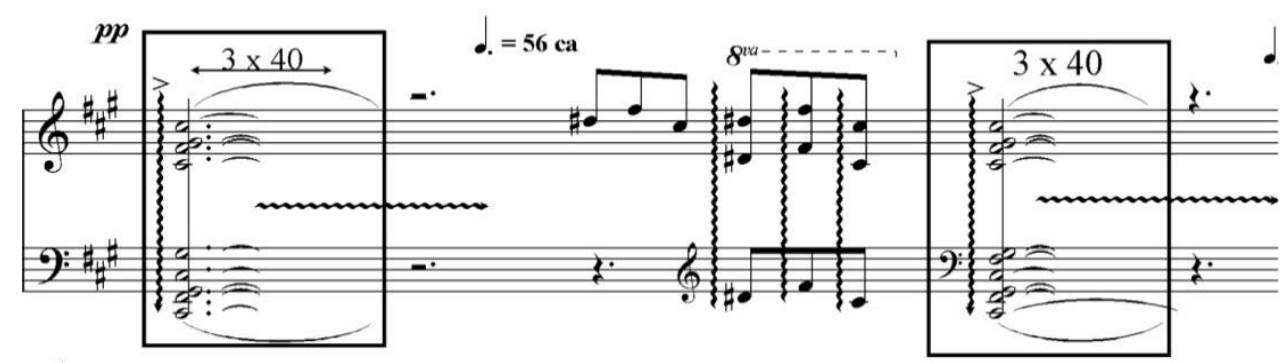

Ex.14b-Módulo 6 com Ideia 1 justaposta a Ideia 2: altura determinada e duração indeterminada (Expressão Anímica de Eunice Katunda).

Módulo 7(A). A compositora não deixa claro onde será executado esse Módulo. Sugerese que seja tocado no teclado (in waves), criando efeitos de ondas, intensificado pelos crescendos e decrescendos. Explora a ressonância dos sons, amparado pela sustentação do pedal direito do instrumento. A notação sugere apenas a trajetória que deve ser seguida pelo intérprete para que se crie o efeito de ondas. É aconselhável que o intérprete determine no estudo quais notas serão o pivô neste percurso, o que permitirá um maior equilíbrio sonoro que se remeta a ondas. O Módulo não apresenta nenhuma determinação rítmica e a liberdade do intérprete se faz confirmar com a palavra ad libitum. 
A interpretação envolve a improvisação sobre um tipo de notação indicativa, pois apenas delineia o trajeto marcado pelos sinais, definido apenas como região. Sugere-se que o intérprete escolha o punho fechado para execução e o polegar aberto como guia das notas pivô. Observe-se o Ex.15:

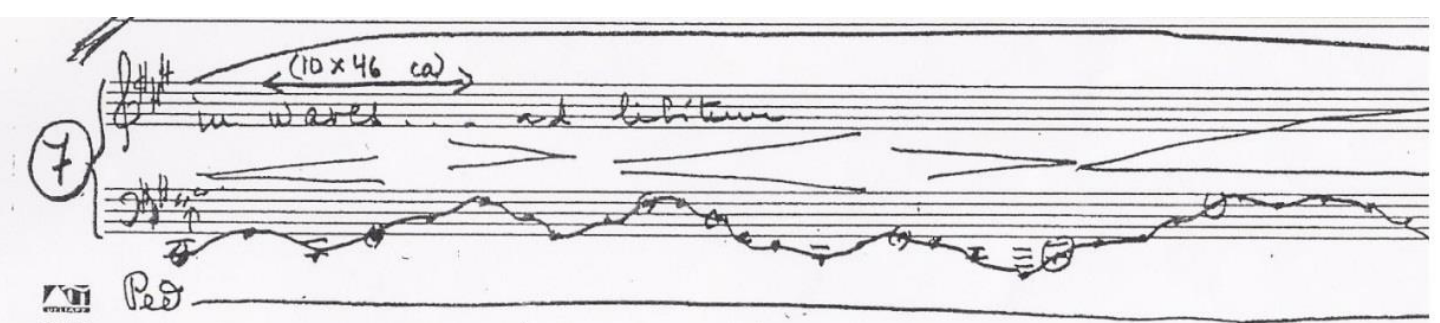

Ex.15-Módulo 7 com efeitos de ondas improvisadas pelo intérprete: elementos indeterminados (Expressão Anímica de Eunice Katunda).

Módulo 8(A). Tocado inteiramente no teclado. A ldeia 1 é novamente apresentada com variação rítmica. O tempo, duração, altura, articulação e dinâmica são determinados e apresentam notação exata. Apenas com a reapresentação da Ideia 1 surgem elementos indeterminados, como duração, com tipo de notação aproximada. A nomenclatura afrettando (acelerando gradativamente), é um elemento indeterminado de andamento, ficando a cargo do intérprete essa escolha. A mesma ldeia 2 do Módulo 6 se repete com uma pequena variação no ritmo e timbre sobre um ostinato na linha inferior. Na indicação de tempo, verifica-se que a compositora empregou uma mesma pulsação para o Módulo (=56). Ao apresentar os mesmos elementos da Ideia 1, com outra figuração, o intérprete deverá fazer a execução relativa deste trecho. Pode-se cogitar que esse Módulo é a continuação do Módulo 6, interrompido apenas pelos efeitos tímbricos do Módulo 7, pois apresentam os mesmos elementos. O intérprete deve explorar a ressonância do último bloco sonoro, permitindo que se dê seguimento ao Módulo seguinte. Observe-se o Ex.16:

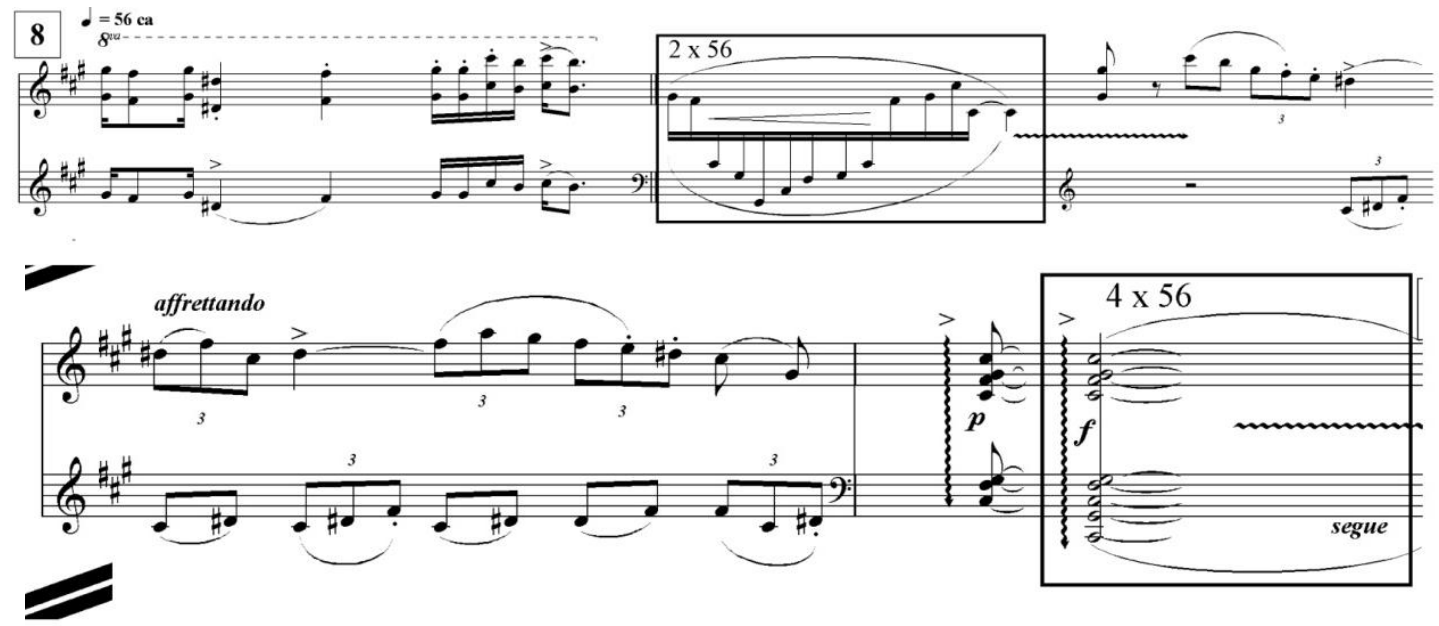

Ex.16-Módulo 8 com variação da Ideia 2 sobre ostinato: elementos determinados (Expressão Anímica de Eunice Katunda).

Módulo 9(A/B). É tocado primeiramente no encordoamento do piano, com dedeira. A altura é um elemento determinado com tipo de notação exata, porém o tempo e a duração são indeterminados. O tipo empregado para a duração é notação indicativa, expressa através de uma linha contínua de comprimento proporcional. Não está especificado o 
tempo deste Módulo, portanto cabe ao intérprete tomar decisões, realizando o ritmo e as durações através da avaliação dos comprimentos dos sons por meio de uma correlação espaço-tempo. Na $2^{a}$ parte do Módulo, notas tocadas no teclado são sobrepostas aos sons no encordoamento, explorando a diversidade tímbrica. Neste trecho as alturas continuam determinadas e diferenciadas pelo tempo que agora se apresenta determinado: $(4 \times 56),(3 \times 56),(2 \times 56)$. As figuras, breve e longa colocadas na pauta apenas sugerem ao intérprete que deve haver uma sustentação desses sons, mas não faz referência ao valor real. O intérprete dará relevância à linha contínua e decidirá pela sua experiência e bom gosto. Sugere-se também que o intérprete meça a intensidade com que tocará os sons nas teclas, para que não se perca o brilho dos sons produzidos no encordoamento. Fica implícito o uso do pedal direito do instrumento. Observe-se o Ex.17:

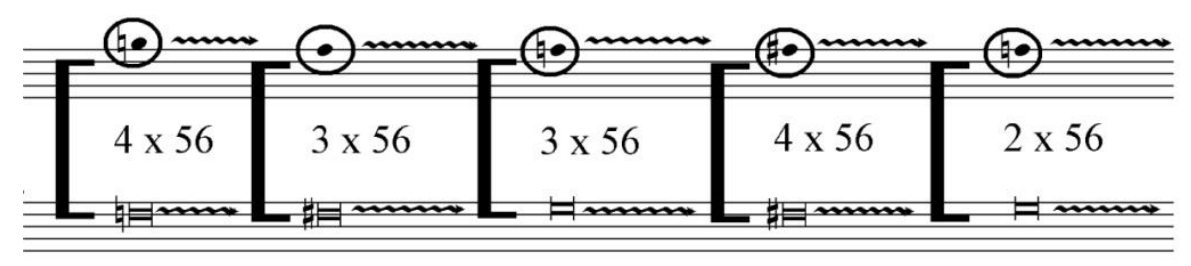

Ex.17-Módulo 9 com dedeira no encordoamento do piano: altura determinada, duração e tempo indeterminados. (Expressão Anímica de Eunice Katunda).

Módulo 10(A). Tocado no teclado do piano. Todos os elementos são determinados com tipo de notação exata. Apenas a fermata, cesura (suspensão da emissão sonora) e o final do Módulo apresentam duração indeterminada. $O$ intérprete deverá prolongar os sons registrados com uma linha de prolongamento até o compasso seguinte (utilizando o pedal do instrumento), permitindo a ressonância destes sobre os novos elementos que surgem. Atenção especial ao emprego do pedal nas duas últimas notas do Módulo: levantar o pedal na nota Mi e abaixá-lo somente após tocar o Dó como mostra o Ex.18:

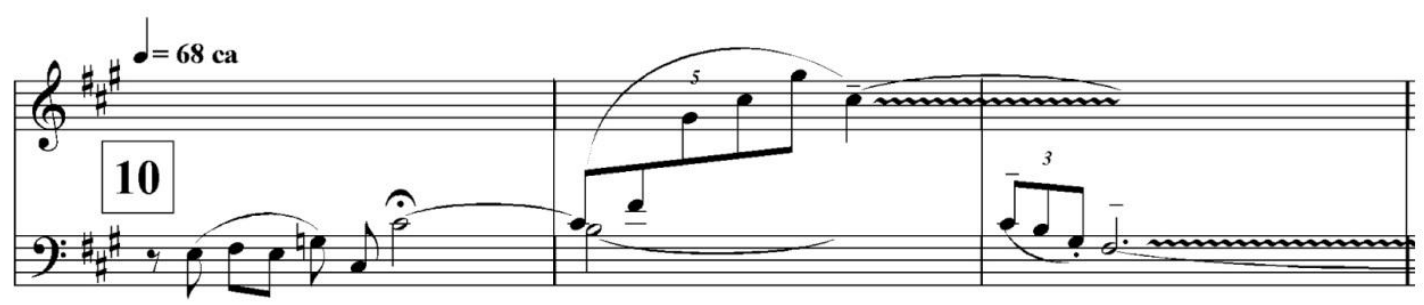

Ex.18-Módulo 10: notação exata e duração indeterminada proporcional ao comprimento das linhas. (Expressão Anímica de Eunice Katunda).

Módulo 11(A/B). Inicialmente executado no encordoamento do piano com um prato de percussão e a seguir fazendo uma sobreposição com o teclado. A altura é um elemento indeterminado, já que apenas a região fica sugerida (registro médio), empregando um tipo de notação aproximada. Enquanto se ouve a ressonância dos sons percutidos pelo prato sobre o encordoamento, toca-se no teclado uma melodia cuja notação é exata. Haverá a reverberação de várias alturas, soando como um cluster nas cordas. O tempo e a duração estão determinados, o intérprete deve observar que a peça contém subdivisão de compasso, porém não há coerência com a duração proposta. Com a notação exata do ritmo (na linha inferior deste Módulo), o intérprete deverá aguardar o tempo antes de entrar com a baqueta no compasso seguinte. A compositora não registra uma nova utilização da baqueta, mas isto se confirma pela similaridade da notação empregada. $O$ parâmetro rítmico se sobressai, principalmente pelo caráter do timbre, realizando um 
diálogo entre o ritmo do encordoamento e o do teclado. Fica a critério do intérprete a escolha do tempo certo da entrada das últimas notas do Módulo, já que se encontra registrado até desaparecer. Propõe-se também que se execute este trecho após o amortecimento dos sons vibrados pela baqueta. No final do Módulo reaparece a ldeia 1 seguida de duas notas no extremo grave do instrumento, em sfz. Neste caso, a duração é indeterminada. Estão demonstrados nos Exs.19a e 19b:

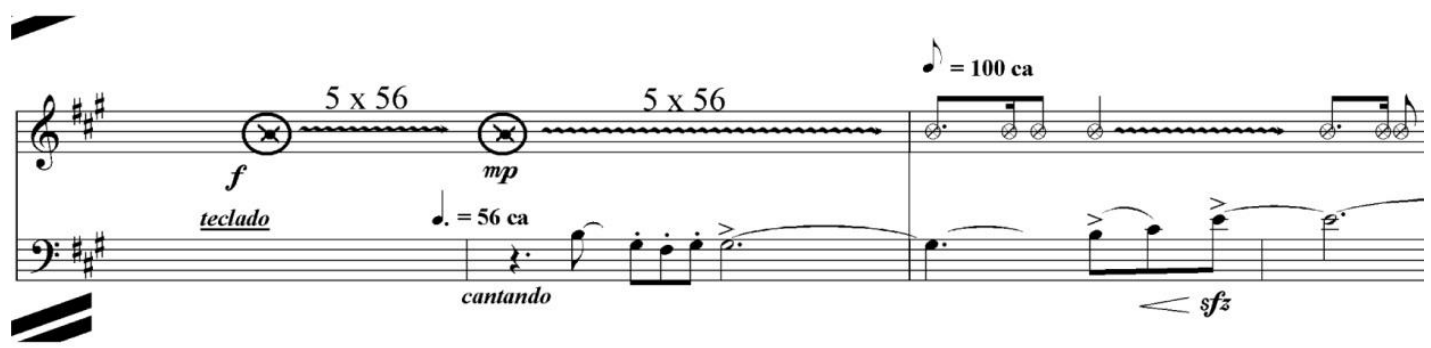

Ex.19a-Módulo 11 com prato no encordoamento: tempo e duração indeterminados.

(Expressão Anímica de Eunice Katunda).

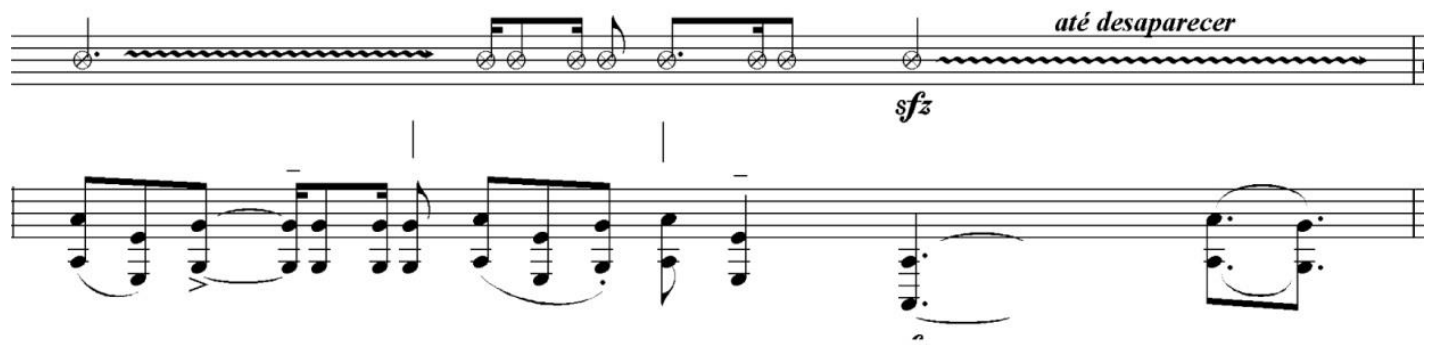

Ex.19b-Módulo 11 com baqueta no encordoamento: tempo e duração indeterminados. (Expressão Anímica de Eunice Katunda).

Módulo 12(A). Inteiramente executado no teclado do piano. De caráter rítmico, apresenta notação exata para todos os elementos musicais. O tempo é determinado - bem medido. $\mathrm{Na}$ linha do baixo aparece um ostinato em grupo de quatro notas repetidas nove vezes na região mais grave do instrumento. Sobre este ostinato ocorre uma linha melódica que traz recordação da mesma Ideia do Módulo 8, porém com variação quanto ao ritmo. Todos os parâmetros dos sons estão determinados. A maior dificuldade para o intérprete é manter regular a subdivisão rítmica sobre o ostinato até o final. Observe-se o Ex.20:

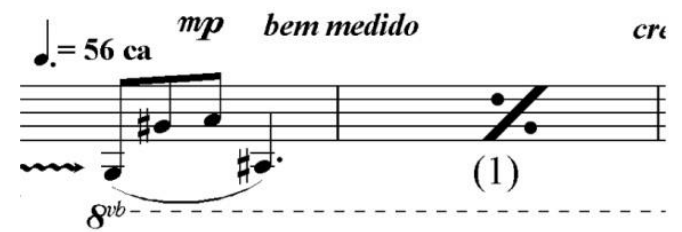

Ex.20-Módulo 12 com ostinato e elementos estruturais determinados. (Expressão Anímica de Eunice Katunda).

Módulo 13(A/B). Tocado no teclado e no encordoamento do piano. No teclado aparecem clusters cromáticos com as duas mãos espalmadas sobre as teclas. No encordoamento, cordas beliscadas com dedeiras. A altura e a dinâmica possuem notação exata nas duas modalidades. O tempo e a duração são indeterminados e o tipo empregado para a duração é notação indicativa, expressa através de uma linha contínua de comprimento proporcional. O tempo também não está determinado e cabe ao intérprete tomar decisões, realizando o ritmo e as durações através da avaliação dos comprimentos dos 
sons por meio de uma correlação espaço-tempo. Quanto à dinâmica, a compositora sugere que o intérprete equilibre entre os sons produzidos nas cordas beliscadas e os clusters. Quanto aos clusters, o intérprete deve utilizá-lo dando tratamento percussivo ao piano, observando que os limites superiores e inferiores das alturas estão determinados com exatidão. A compositora sugere: $(x)$ polegar, na horizontal, abrange as teclas brancas - escolher uma melhor forma de posicionamento das mãos, conforme sua estrutura para que todos os sons sejam atacados simultaneamente. Observe-se o Ex.21:

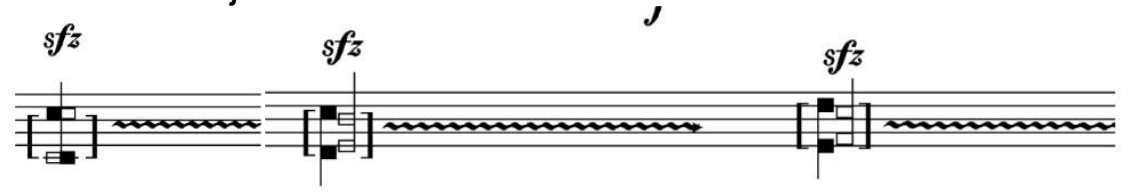

Ex.21-Módulo 13. Clusters cromáticos com âmbito determinado. (Expressão Anímica de Eunice Katunda).

Módulo 14(A). Inteiramente tocado no teclado. Este Módulo está construído sobre a Ideia 1, variada em andamento, ritmo, intensidade, região e tempo. Para que se explore a ressonância desses grupos de sons, reforçados pelo emprego do pedal direito do instrumento, a duração tem notação aproximada, enfatizada pela expressão - deixa soar e uma linha sinuosa que sugere o declínio das ondas sonoras. A fermata sobre a barra de compasso no final do Módulo também é um elemento que colabora com a indeterminação da duração. Como a compositora não coloca símbolo de compasso, apesar de dividir em barras, utiliza a palavra rápido sobre um grupo de quiálteras (sete e cinco notas). Sugerese que este trecho seja interpretado atribuindo valores proporcionais ao sugerido anteriormente $(=144)$ até o final do Módulo. Os demais elementos são determinados e possuem notação exata. É bastante significativa a exploração tímbrica: contrastes entre forte e pianíssimo, regiões extremas do piano, acentos e o recurso do pedal direito do instrumento para efeitos de ressonância. Observe-se os Exs. 22a e 22b:

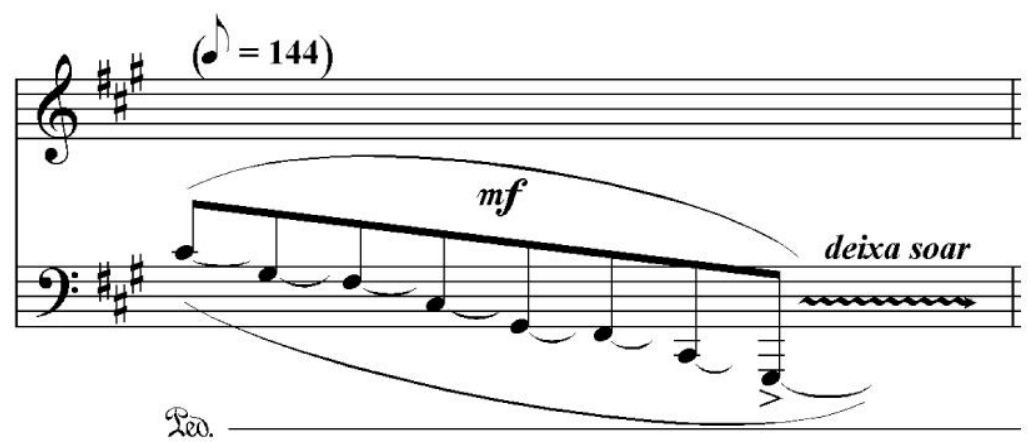

Ex.22a-Módulo 14 com Ideia 1 e suas variações em tempo, ritmo e dinâmica. (Expressão Anímica de Eunice Katunda).

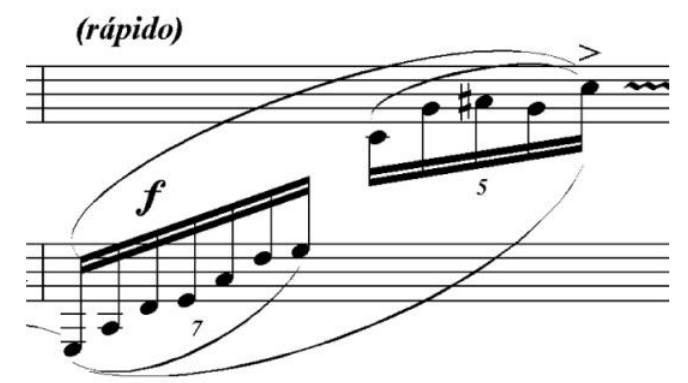

Ex.22b-Módulo 14 com Ideia 1 em quiálteras.

(Expressão Anímica de Eunice Katunda). 
Módulo 15(A). Apresenta-se em um trecho breve tocado no teclado. Inicia-se com a Ideia 1 na região aguda com variação rítmica e sobreposto a notas na região grave, cuja articulação emprega staccatos e sfz. Todos os elementos musicais são determinados e o tipo é notação exata, exceto para a fermata na barra final e a cesura que antecede as três notas finais, executadas de $f f$ a $p p$, na região grave. Como recurso de diversidade, 0 intérprete deverá ser preciso e seguir a notação rítmica estipulada pela compositora, mantendo o valor exato de cada som, demonstrado no Ex.23:

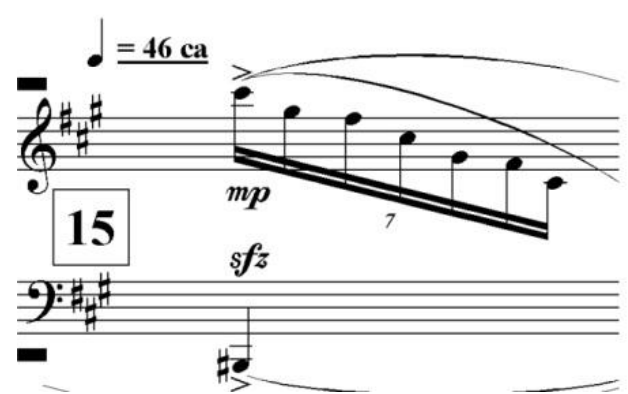

Ex.23-Módulo 15 com Ideia 1 e variação rítmica sobreposta a notas na região grave. (Expressão Anímica de Eunice Katunda).

Módulo 16(B/A). Inicia-se no encordoamento do piano com uso da dedeira seguido da entrada no teclado. A altura é um elemento determinado e tem notação exata nas duas modalidades. A duração e o tempo são indeterminados e o tipo empregado para a duração é notação indicativa, expressa através de uma linha contínua de comprimento proporcional. A compositora não especifica o tempo deste Módulo e cabe ao intérprete decidir, realizando o ritmo e as durações através da avaliação dos comprimentos dos sons por meio de uma correlação espaço-tempo. Para cada nota beliscada nas cordas uma é executada simultaneamente no teclado, exceto sobre a quinta nota do teclado, com somente três cordas dedilhadas. $O$ pedal do instrumento deverá ser mantido todo 0 tempo. Observe-se o Ex.24:

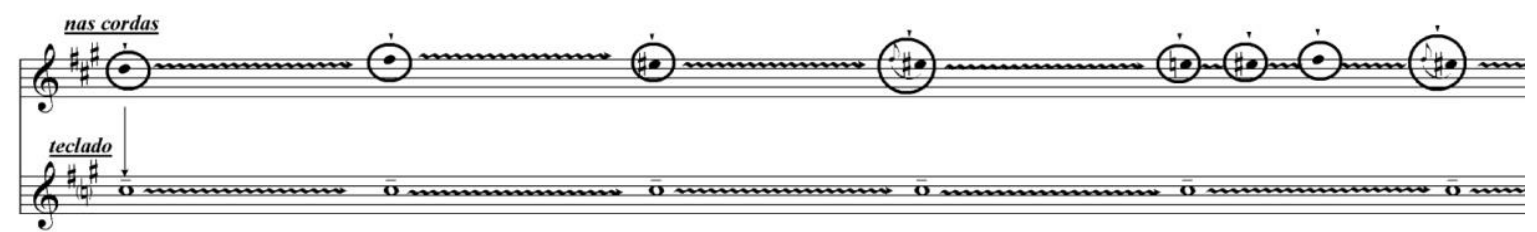

Ex.24-Módulo 16: altura determinada, tempo e duração indeterminados. (Expressão Anímica de Eunice Katunda).

Módulo 17(A). Inteiramente tocada no teclado. Inicia-se com a Ideia 1 em menor extensão, com variação rítmica e acréscimo de elementos. Essa ldeia 1 vem justaposta com a Ideia 2, também com variação rítmica e mudança de região. Todos os elementos são determinados e possuem notação exata. Apenas na apresentação da ldeia 1 a duração é indeterminada com tipo de notação aproximada, explorando a ressonância dos sons. A característica principal desse Módulo é o contraste entre as duas Ideias com exploração do timbre: Ideia 1- região grave e Ideia 2 - região aguda, com dinâmica $m f$ a pp. Ocorre que o tempo está sugerido $(=56)$ proporcionando a subdivisão exata dos valores, porém a linha contínua e sinuosa no final de cada compasso propõe (3x56) com a expressão deixar vibrar. Cabe ao intérprete decidir se essa duração é suficiente para que ocorra o declínio dos sons. Depois da terceira reapresentação dessa ldeia 1, observa-se que a compositora não determina a duração, apenas coloca uma linha ou 
deixa sem nenhuma notação. Apesar disso, há a necessidade de que se prolongue o som, mesmo que este efeito dure menos que o anterior. Notam-se também acentos colocados sobre as notas, como mostrado no Ex.25:

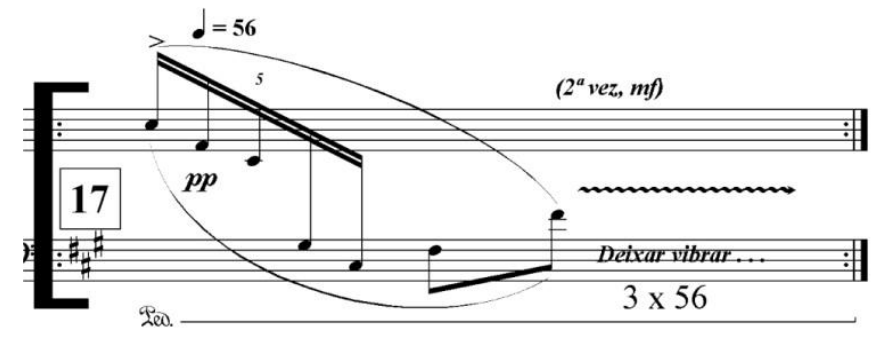

Ex.25-Módulo 17 com Ideia 1: duração indeterminada. (Expressão Anímica de Eunice Katunda).

Módulo 18(A). Tocado no teclado, percorre toda sua extensão em movimentos rápidos e precisos. Todos os elementos são determinados e a notação é exata. Exceção para a duração nos finais das notas longas e após o cluster que apresentam notação aproximada. O cluster cromático apresenta uma extensão maior e está indicado para ser tocado com os antebraços, deixando vibrar (ca. de 10 vezes 56 batidas por minuto), similar à duração empregada no Módulo 1. Todo o Módulo deve ser tocado em $f$, crescendo molto e com repetição ad libitum. A repetição contínua da série de alturas dadas sugere um crescendo molto, o que também pode sugerir um aumento do andamento. O término da repetição pode ser salientado dando ênfase às três últimas notas até a primeira do grupo seguinte. Fica a critério do intérprete em quantas vezes repetirá o trecho. É o Módulo mais intenso da peça, demonstrado no Ex.26:

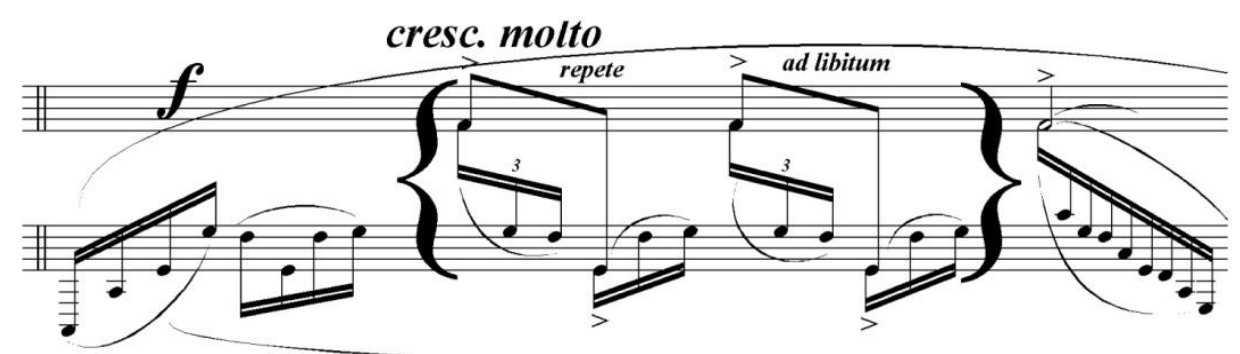

Ex.26-Módulo 18: repetição ad libitum. (Expressão Anímica de Eunice Katunda).

Módulo 19(B). Este Módulo realiza um contraste com o Módulo anterior em andamento (muito lento) e em timbre (cordas beliscadas). A princípio executado nas cordas com a dedeira e mais tarde utilizando a dedeira e a unha para tocar em cordas duplas. A altura e a intensidade são elementos determinados e possuem notação exata. A duração é indeterminada e o tipo empregado é a notação indicativa, expressa através de uma linha contínua de comprimento proporcional. O tempo está determinado em muito lento e menos lento. Observe esta demonstração no Ex.27: 


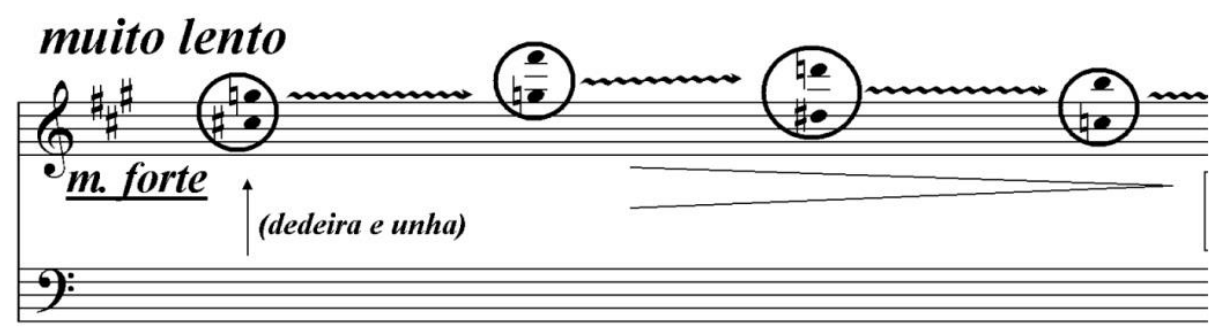

Ex.27- Módulo 19. cordas duplas beliscadas com altura determinada e duração indeterminada. (Expressão Anímica de Eunice Katunda).

Módulo 20(B). Inteiramente tocado no encordoamento, com dedeira ou com a borda do prato, indicado pela compositora. O tempo determinado de (76 cada) e (46 ca) sugere que cada indicação do glissando sobre o encordoamento dure o tempo mencionado e que se sustente o pedal do instrumento após a execução de três glissandi na região grave e quatro na região média, explorando a ressonância desses sons. Para este efeito a duração é indeterminada, com notação aproximada, proposta pela linha sinuosa de declínio do som. Não apresenta altura determinada, apenas glissandi ascendentes por regiões: grave, médio e agudo. A dinâmica e o ritmo são determinados e possuem notação exata. O Módulo 20 realiza um desenho ascendente, partindo da região grave, percorrendo toda extensão até a região aguda (rall. e subindo). Observem-se os diferentes tipos de setas para os glissandi, servindo de orientação para o intérprete. Quando a altura é colocada entre parênteses indica que se deve partir desta em diante para realizar o glissando; quando não consta essa indicação se deve partir de qualquer uma, apenas tendo em vista a região. Observe-se o Ex.28:

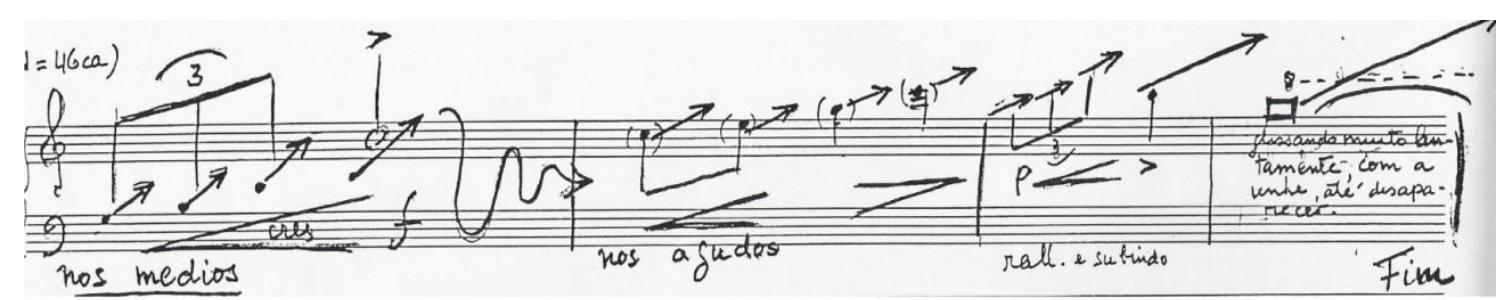

Ex.28-Módulo 20: glissandi no encordoamento do piano, região e duração determinadas.

(Expressão Anímica de Eunice Katunda).

\section{Considerações Finais}

No estudo da peça foi possível fazer um reconhecimento dos diversos elementos de indeterminação e de efeitos, exigindo do intérprete alguma escolha, conforme seus critérios particulares. A peça delega certa liberdade ao intérprete ao utilizar tipos de notação diferenciada da tradicional e ao solicitar efeitos de ressonância dos sons. $\mathrm{Na}$ estruturação da peça a compositora dá ao intérprete indicações nas quais a indeterminação possibilita uma margem de participação criativa, porém exerce certo controle sob suas ações. Alguns Módulos colocam o intérprete como responsável pela realização da obra; no entanto, haverá sempre um guia que o direcionará, a altura e/ou a duração. As instruções da compositora quanto aos procedimentos, símbolos de notação e acessórios são colocadas diretamente na partitura. No âmbito geral predomina o emprego da notação exata (Módulos 3, 6, 8, 10, 12, 14, 15 e 17), mas também emprega a notação indicativa e notação aproximada. As indicações de altura quase sempre são exatas, enquanto a duração é aproximada ou indicativa. Apesar desta proposta subjacente à coparticipação criativa, a peça apresenta uma Ideia que lhe dá unidade (Módulo 1). Devese aqui relevar alguns pontos: se a duração está determinada com marcação de 
metrônomo, fica contraditória a linha contínua colocada à frente. Para esse efeito está implícito o uso do pedal do instrumento, mas este nem sempre é indicado pela compositora. Cabe ao intérprete tomar essa decisão, priorizando o efeito das ressonâncias. Outra atitude contraditória é a utilização da barra de compasso, desnecessária, já que não existe divisão métrica. Assim também ocorre com a armadura de clave.

O preparo desta peça exige do intérprete, além da compreensão dos símbolos e notações (aqui apresentados, já que não há uma bula), também a busca de um acessório adequado para a execução. Diga-se da escolha das baquetas, do prato e da dedeira para a execução no encordoamento. Passada por essa experiência, a autora deste trabalho afirma que a ponta da baqueta deve ser pequena o suficiente para que, ao percutir o encordoamento do piano, atinja apenas uma corda - a altura sugerida pela compositora pois de tamanho maior, percutiria duas ou mais cordas. Ainda, para a escolha do prato, deve-se levar em consideração o seu tamanho. A região colocada para que se percuta 0 prato nos encordoamentos esbarra em um problema de construção do piano - as barras de aço que sustentam a tábua harmônica. Portanto, o prato deve ser suficientemente pequeno para que se encaixe dentro dessas divisões entre as barras. A dedeira, peça comum de plástico, tem de ter a ponta extremamente dura para que ao percutir a corda permita-a vibrar, sem emitir o som causado pela retração da ponta da dedeira. Talvez possa se sugerir aqui a troca da dedeira por um plectro do tipo que se executa ao bandolim, o que dará maior liberdade de execução. Esta seleção dos acessórios, assim como a dos modos de ataque e de variações timbrísticas, deve ser uma escolha antecipada do intérprete, que confere ao próprio ato da preparação e execução, um campo de possibilidades, um campo de diferentes resultados sonoros, um caráter de desafio e pesquisa. Esse aspecto da composição musical estimula e influencia o intérprete, pois cada leitura oferece possibilidades de uma execução única, vistos o não determinismo da notação e/ou das propostas de interpretação engendradas pela compositora.

\section{Referências}

ANTUNES, Jorge. Notação na música contemporânea. Brasília: Sistrum,1989.

BRINDLE, Reginald Smith. The New Music: The Avant-Garde since 1945. New York: Oxford Press, 2003.

CAMPOS, Augusto de. Música de Invenção. São Paulo: Perspectiva,1998.

Correspondence Boulez-Cage. Paris: Christian Bourgeois,1991

EUNICE KATUNDA toca música contemporânea. Jornal A Tribuna, Santos, 27 de setembro de 1979.

KARKOSCHKA, Erhard. Notation in new Music. London: Universal Edition, 1972.

KATER,Carlos. Música Viva e J.H. Koellreutter: movimentos em direção à modernidade. São Paulo: Musa/Atravéz, 2001.

Eunice Katunda: musicista brasileira. São Paulo: Anablume, 2001.

KOELLREUTTER, Hans Joachim. Terminologia de uma nova estética da música. Porto Alegre: Movimento, 1990.

KOSTKA, Stefan. Material and Techniques of Twentieth-Century Music.3rd ed. New Jersey: Prentice-Hall, 2006.

NEVES, José Maria. Música Contemporânea Brasileira. São Paulo: Ricordi, 1977.

O Estado de São Paulo. Para lembrar os autores do Manifesto Música Viva. São Paulo, 29 de setembro de 1978, p.18.

SOUZA, Iracele Vera Livero. Santoro: Uma História em Miniaturas: um estudo analítico-interpretativo dos Prelúdios para Piano de Claudio Santoro. 2003. 2v. 761 p. Dissertação (Mestrado), Instituto de Artes, Universidade Estadual de Campinas, 2003.

Louvação a Eunice: um estudo de análise da obra para piano de Eunice Katunda. Tese de

Doutorado, Campinas, Instituto de Artes - UNICAMP, 2009. 
SANTOS, Antonio Eduardo: Os Des-Caminhos do Festival Música Nova: (FMN-um veículo de comunicação dos caminhos da música contemporânea), 2003. Tese (Doutorado) Departamento de Comunicação e Semiótica, PUC-SP, São Paulo, 2003.

SIMMS, Bryan. Music of the Twentieth Century: Style and structure. NY: Schirmer, 1986.

ZAMPRONHA, Edson. Notação, Representação e Composição: um novo paradigma da escritura musical. São Paulo: Anablume/Fapesp, 2000.

\section{Notas}

${ }^{1}$ A expansão da composição serial entre os compositores europeus do pós-guerra se fez mais notável devido ao fato das obras de Schoenberg, Berg e Webern ficarem indisponíveis até o primeiro Ferienkurse für Neue Musik, em Darmstadt, em 1946. (SIMMS: 1986, p.344.)

2 Embora, nos EUA, sob a influência de Milton Babitt, o serialismo integral continuava a crescer.

${ }^{3}$ Explorado primeiramente por Schoenberg e Webern, em torno de 1910.

${ }^{4}$ No dodecafonismo estrito as notas da série não podem ser repetidas até todas as outras onze notas terem sido apresentadas. Na Serenata l (1957) de Berio, as notas repetidas começam a ocorrer no quarto compasso sem que todas as notas cromáticas tenham sido empregadas. Há grupos de notas tonais e repetições em oitava. Boulez, na Improvisations sur Mallarmé (1957), para soprano e conjunto de percussão, repete grupos de notas de forma insistente no decorrer da peça.

${ }^{5} \mathrm{Em}$ Quantitäten de Bo Nillson, as frases são formadas por quatro notas em três tempos, quatro em cinco tempos e três batidas no tempo de quatro. Como não há indicação de metro ou tempo, cabe ao intérprete encontrar seu ponto de partida. Em Exercices pour Piano, Pousseur evitou os rigores da notação precisa com a introdução de valores um pouco imprecisos como apojaturas com quatro durações diferentes, e silêncios ordenados com diferentes durações.

${ }^{6}$ Como parafusos, com e sem porcas, borrachas, entre outros.

7 Em Bacchanale (c.1938-1940), o piano foi transformado em um conjunto de percussão que poderia produzir tanto notas de altura fixa quanto ruidos tímbricos. Seguem-se Sonatas e Interlúdios (1946-48) para Piano Preparado, sua obra mais substancial neste contexto, na qual o compositor procura transmitir um panorama de emoções.

${ }^{8} \mathrm{~A}$ indeterminação da altura era de mais difícil aceitação pelos europeus do que a do tempo, porém Stockhausen utilizaria a indeterminação de alturas no início dos anos 60 no seu Mixtur (1964) para cinco grupos orquestrais.

9 Grupo Música Viva, atuante entre 1940-1950, liderado por J. H. Koellreutter, era formado pelos compositores Claudio Santoro, Guerra Peixe, Edino Krieger e mais tarde, Eunice Katunda.

10 "Deste modo, Claudio Santoro tenderá temporiaramente para o serialismo, abandonando-o mais tarde em prol de maior liberdade de expressão; Edino Krieger buscará igualmente no serialismo soluções para sua problemática específica, no momento em que se afasta do nacionalismo. Outros compositores usaram apenas princípios seriais de estruturação, mas se reservando total independência com relação a esta técnica composicional." (NEVES, José Maria. Música Contemporânea Brasileira. São Paulo: Ricordi, 1977, p.154).

11 Os demais signatários do manifesto são: Régis Duprat, Sandino Hohagen, Júlio Medaglia e Alexandre Pascoal. Invenção. ano 2 n. 3, junho. São Paulo: Invenção, 1963, p.6.

12 Eunice interpreta de Koellreutter: Música 1941 e Tanka V (1977), de Guerra-Peixe, Música $n .1$ (1945), de Santoro, Paulistana n. 6 (1954) e de sua autoria, Sonatina 1946 e Expressão Anímica (1979).

${ }^{13}$ Esta nomenclatura também foi utilizada por Koellreutter $(1990$, p. 98$)$ que se refere à grafia da notação contemporânea como: notação precisa, notação aproximada, notação roteiro e notação gráfica.

14 Kausika faz referência a um determinado tipo de raga Hindu que mais frequentemente representa 0 contexto de uma linha melódica. In GURUGE, Ananda. The Society of the Ramayana. New Delhi: Shakti Malik, 1991, p.182.

Iracele Vera Livero de Souza é Doutora e Mestre em Música pela UNICAMP/SP. Suas pesquisas, ambas financiadas pela CAPES, apresentam uma análise interpretativa de obras para piano dos compositores do Grupo Música Viva, Claudio Santoro e Eunice Katunda, enfatizando a importância destes na produção musical brasileira do século XX. A ênfase do seu trabalho está voltada às áreas de estudo em análise musical e interpretação, atuando principalmente nos temas: Análise Musical, Piano, Música 
Brasileira, Século XX-XXI. Possui uma significativa produção científica em análise musical e práticas interpretativas, que incluem artigos e comunicações em congressos nacionais e internacionais. Foi professora de matérias teóricas, com enfoque principal na Análise Musical, na USC - Universidade Sagrado Coração de Jesus, Bauru-SP e piano na EMESP (Escola de Música do Estado de São Paulo). É pesquisadora colaboradora no CIDDIC/UNICAMP-SP e professora no Instituto de Artes na mesma Universidade. 